\begin{tabular}{l|l|l|l} 
Case Reports in & $\begin{array}{l}\text { Case Rep Neurol 2010;2:133-138 } \\
\text { DOl: 10.1159/000321844 }\end{array}$ & $\begin{array}{l}\text { Published online: } \\
\text { November 3, 2010 }\end{array}$ & $\begin{array}{l}\text { O 2010 S. Karger AG, Basel } \\
\text { ISSN 1662-680X } \\
\text { www.karger.com/crn }\end{array}$ \\
\hline
\end{tabular}

\title{
Fulminant Meningoencephalitis as the First Clinical Sign of an Invasive Pituitary Macroadenoma
}

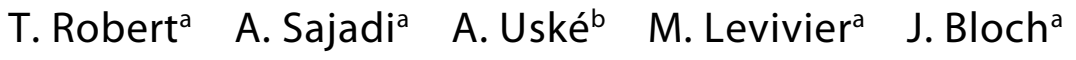 \\ Departments of a Neurosurgery and ${ }^{\mathrm{b}}$ Neuroradiology, Centre Hospitalier \\ Universitaire Vaudois, Lausanne, Switzerland
}

\section{Key Words}

Pituitary adenoma $\cdot$ Meningoencephalitis

\begin{abstract}
We report the case of a young woman who presented with an acute fulminant meningoencephalitis as the first sign of an invasive pituitary macroadenoma. This rare and dramatic complication is described in detail, and the different management steps, from the lumbar puncture to the bifrontal craniectomy, are discussed. In conclusion, this clinical presentation highlights the importance of early diagnosis and urgent management of this uncommon complication.
\end{abstract}

\section{Introduction}

The most frequent clinical manifestations of pituitary macroadenomas are endocrinological disturbances or visual loss $[1,2]$. These clinical signs can be gradual if the tumor is growing progressively, or acute if an infarct or a hemorrhagic event takes place in the tumor. More rarely, when a macroadenoma is growing towards the skull base, it can progressively erode the floor of the sella into the sphenoid sinus, leading to cerebrospinal fluid (CSF) leakage [1]. A CSF fistula is a serious event, since it is an open pathway between the intra- and extradural compartments. Therefore, in order to avoid infectious complications, tumor removal and skull base defect repair are mandatory.

Here, we describe the case of a young healthy patient who presented with acute fulminant meningoencephalitis as the first sign of an invasive pituitary macroadenoma. It is important to be aware of this rare but dramatic presentation because early and aggressive management may change the course of the disease. 


\begin{tabular}{l|l|l|l} 
Case Reports in & $\begin{array}{l}\text { Case Rep Neurol 2010;2:133-138 } \\
\text { DOI: 10.1159/000321844 }\end{array}$ & $\begin{array}{l}\text { Published online: } \\
\text { November 3, 2010 }\end{array}$ & $\begin{array}{l}\text { ○ 2010 S. Karger AG, Basel } \\
\text { ISSN 1662-680X } \\
\text { www.karger.com/crn }\end{array}$ \\
\hline
\end{tabular}

\section{Case Report}

A 32-year-old woman was admitted to our hospital because of a 24-hour history of acute headache, photophobia, nausea and vomiting. She had no remarkable history of medical or surgical illness. The general and neurological examinations were normal, i.e. no fever and no neck stiffness. The computerized tomography (CT scan) revealed a pituitary mass with suprasellar extension and an infiltration of both cavernous sinuses. The sella was destroyed and the sphenoid sinus filled with tumor tissue (fig. 1). No hemorrhage or hydrocephalus was observed, and the rest of the brain was normal. The biological and endocrinological examinations were normal, and the level of C-reactive protein was $9 \mu \mathrm{g} / \mathrm{dl}$. The diagnostic hypothesis was an invasive, nonfunctioning pituitary macroadenoma grade IV E (Hardy system) with a serum prolactin level of $84 \mathrm{ng} / \mathrm{dl}$. The patient was hospitalized in our neurosurgical department and was given a hydrocortisone substitution.

Ten hours later, the patient presented with fever $\left(39.5^{\circ} \mathrm{C}\right)$, but without neurological sign. The $\mathrm{C}$-reactive protein level was $40 \mu \mathrm{g} / \mathrm{dl}$. Therefore, $2 \mathrm{~h}$ after she became drowsy, a new CT scan was performed that showed a slight but diffuse cerebral edema without obstructive hydrocephalus. At that time, a lumbar puncture (LP) revealed purulent CSF with an opening pressure of $30 \mathrm{~cm}$ of water. Only $6 \mathrm{ml}$ of CSF were removed. The CSF contained $1.53 \mathrm{~g} / \mathrm{dl}$ proteins and $26 \mathrm{mg} / \mathrm{dl}$ glucose, with 12 white blood cells/ $\mu \mathrm{l}$ but no erythrocytes. Streptococcus pneumoniae infection was identified. Rocephine (6 g/day) and vancomycin (750 mg/day) were started $1 \mathrm{~h}$ after the LP. When her Glasgow coma scale fell below 9 , the patient was intubated and transferred to the intensive care unit; at that time, brain stem reflexes were present.

An hour later, a left reactive mydriasis was noted, and the cerebral CT scan was repeated (fig. 2), showing a cerebral edema with slit ventricles and tonsillar herniation, leading to a narrowing of the basal cisternae. It was then decided to insert a neuronavigation-guided right frontal ventricular drain in order to monitor the intracranial pressure (ICP) and to drain the CSF. The ICP was $80 \mathrm{~mm} \mathrm{Hg}$, and the CSF was so viscous that is was not draining off spontaneously. Since the ICP was continuously high despite hyperventilation, sedation, curarization and mannitol, a bifrontal decompressive craniectomy was performed less than $12 \mathrm{~h}$ after the initial neurological signs. Postoperatively, the patient was stabilized and kept under sedation for 4 days. On day 5 , sedation was stopped and the neurological examination revealed signs of decortication on the left side and no reaction to pain on the right side. Brain stem reflexes were present. Electrophysiological studies showed no response to the evoked potentials. Furthermore, the electroencephalogram was silent on the right side and alpha waves were observed on the left side. A magnetic resonance imaging (fig. 3 ) showed multiple bilateral ischemic zones, probably due to both prolonged intracranial hypertension and infectious cortical venous thromboses. Because of all these clinical and paraclinical findings, we decided to stop the intensive medical support, and the patient died 7 days after the decompressive craniectomy.

\section{Discussion}

Pituitary macroadenomas represent $10 \%$ of all brain tumors. It is commonly accepted that they are either diagnosed based on the presence of abnormal endocrinological secretion or by the compression of a surrounding structure. Indeed, enlargement of a pituitary adenoma into the suprasellar area results in an optic chiasm compression which may cause visual field deficits. Because the inferior nasal fibers, which are located in the inferior aspect of the optic chiasm, serve the superior temporal field, the first visual field deficits are frequently bitemporal superior quadrant defects. In addition, suprasellar extension may rarely obstruct the foramen of Monro, leading to obstructive hydrocephalus. Moreover, the tumor can occasionally extend laterally into the cavernous sinus, causing extraocular muscle palsies. Furthermore, about $5 \%$ of pituitary macroadenomas become locally invasive by a diffuse destruction of the sellar floor, leading to nasal obstruction or CSF rhinorrhea [1,3-6].

To our knowledge, even if this phenomenon is not so rare, only 20 isolated cases of spontaneous rhinorrhea in patients harboring pituitary adenomas are described in the 


\begin{tabular}{l|l|l|l} 
Casp Reports in & $\begin{array}{l}\text { Case Rep Neurol 2010;2:133-138 } \\
\text { DOI: 10.1159/000321844 }\end{array}$ & $\begin{array}{l}\text { Published online: } \\
\text { November 3, 2010 }\end{array}$ & $\begin{array}{l}\text { ○ 2010 S. Karger AG, Basel } \\
\text { ISSN 1662-680X } \\
\text { www.karger.com/crn }\end{array}$ \\
\hline
\end{tabular}

literature $[1,3,7,8]$. Direct erosion of the skull base by the tumor is the proposed mechanism. Nutkiewicz et al. [7] hypothesize that a strong and competent diaphragma sellae, possibly coupled with a fold of evaginated arachnoid membrane, may force pituitary tumors to expand inferiorly and favors CSF leakage into the sphenoid sinus, resulting in a direct route of entry for nasopharyngeal organisms. The most common organism is $S$. pneumoniae [4, 9-11]. Among the 20 reported patients with rhinorrhea and untreated pituitary adenoma, only 6 developed meningitis.

Moreover, we found two reports of patients in the literature, who had meningitis associated with a macroadenoma but without rhinorrhea. The first, described by Utsuki et al. [11], is an autopsy report of a patient who died of meningitis associated with a macroprolactinoma. The second case [12] describes a patient with meningitis as the first sign of macroprolactinoma without previous rhinorrhea, who then had a benign clinical evolution.

The case we report here is remarkable as our patient never exhibited CSF rhinorrhea before her admission to the emergency room; this has not been the case in most of the previously reported patients with macroadenoma and meningitis, since they generally presented with episodic CSF leaks. For this reason, we think that it is important to keep in mind that infectious meningitis at the early stage of the disease can mimic pituitary apoplexy, the most frequent acute complication associated with macroadenomas, due to the sudden expansion of the mass as a result of a hemorrhage or infarction within the tumor, leading to abrupt headache with meningismus [2-11,13].

For the management of similar cases who present with headache and nausea/vomiting and have a CT scan showing an invasive macroadenoma with destruction of the sella and no cerebral edema, we recommend to perform a LP at the very beginning of the presentation in order to identify an eventual germ, even if no infection is suspected. If a cerebral edema is observed on the initial CT, the CSF should be sampled via a ventricular drain, or antibiotics should be started empirically if access to CSF is too difficult. We believe now that even a small quantity of CSF retrieved with a LP can precipitate a cerebral herniation; this complication should therefore be avoided. Early and aggressive antibiotic treatment is crucial and has to be initiated as early as possible, since it may change the course of the disease. Meningoencephalitis due to oropharyngeal flora can be fulminant and irreversible, as in our case.

The condition of patients with severe pneumococcal meningitis can deteriorate rapidly and unpredictably, especially in younger patients who frequently develop intracranial hypertension with a fatal outcome [14,15]. Nevertheless, when intracranial hypertension is suspected based on clinical and radiological findings, it is impossible at an early course of the disease to predict the severity and irreversibility of the brain damage, and an aggressive ICP-targeted strategy including bifrontal decompressive craniectomy can significantly improve the neurological status in patients with severe bacterial meningitis $[16,17]$. Although meningoencephalitis is a very severe complication with unpredictable outcome, we recommend to consider this aggressive surgical decompression in the management of patients with resistant elevated ICP. 


\begin{tabular}{c|l|l|l}
$\begin{array}{c}\text { Case Reports in } \\
\text { Tellu:1:1) }\end{array}$ & $\begin{array}{l}\text { Case Rep Neurol 2010;2:133-138 } \\
\text { DOl: 10.1159/000321844 }\end{array}$ & $\begin{array}{l}\text { Published online: } \\
\text { November 3, 2010 }\end{array}$ & $\begin{array}{l}\text { O 2010 S. Karger AG, Basel } \\
\text { ISSN 1662-680X } \\
\text { www.karger.com/crn }\end{array}$ \\
\hline
\end{tabular}
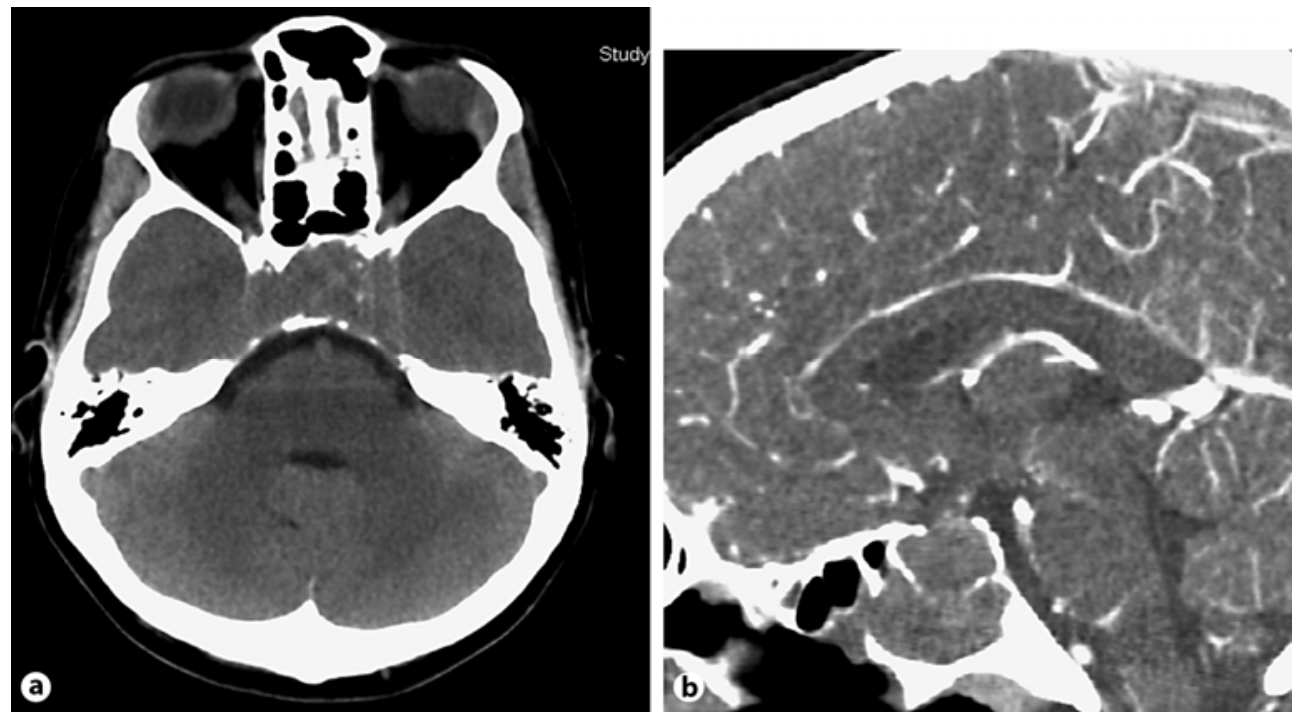

Fig. 1. a Axial CT scan showing the pituitary mass with effraction of the sinuses. b Sagittal CT scan demonstrating invasion of the sphenoid sinus by the extension of the macroadenoma with the destruction of the sella turcica.
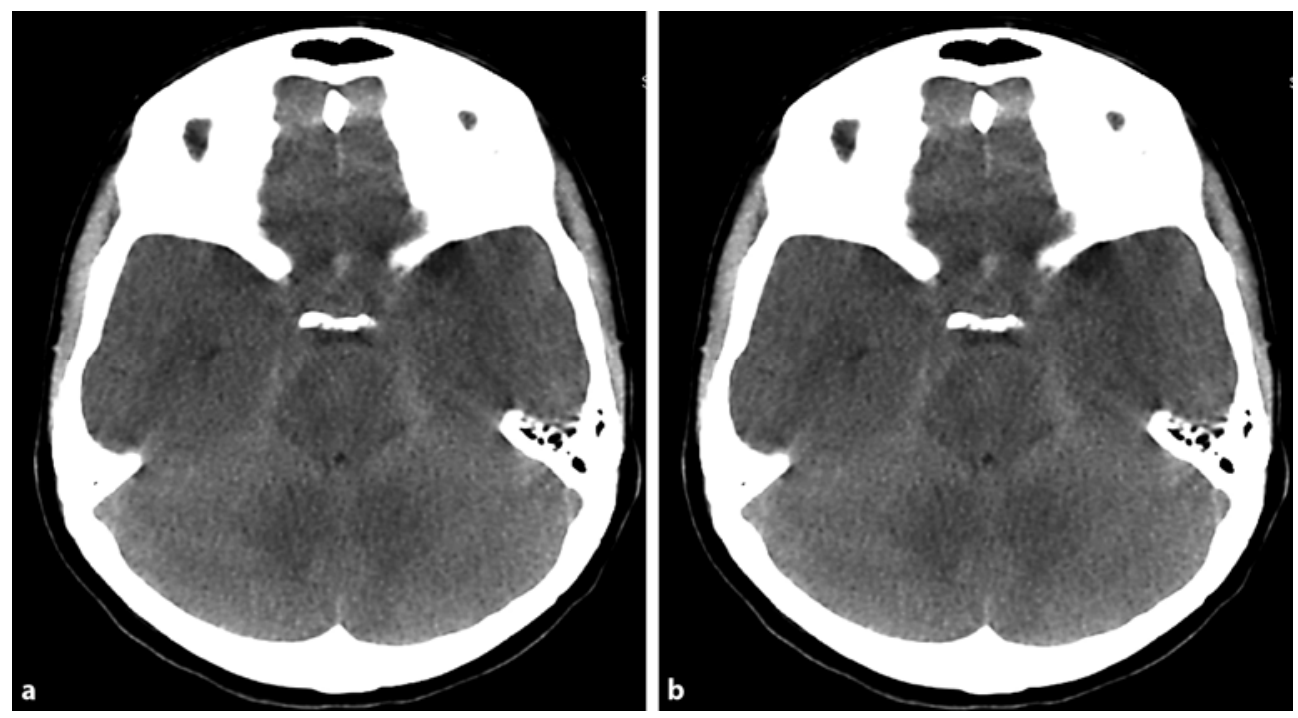

Fig. 2. Axial CT scan obtained when the patient had a left mydriasis: diffuse cerebral edema. The basal cisterns are not visible. 


\begin{tabular}{l|l|l|l} 
Case Reports in & $\begin{array}{l}\text { Case Rep Neurol 2010;2:133-138 } \\
\text { DOl: 10.1159/000321844 }\end{array}$ & $\begin{array}{l}\text { Published online: } \\
\text { November 3, 2010 }\end{array}$ & $\begin{array}{l}\text { ○ 2010 S. Karger AG, Basel } \\
\text { ISSN 1662-680X } \\
\text { www.karger.com/crn }\end{array}$ \\
\hline
\end{tabular}
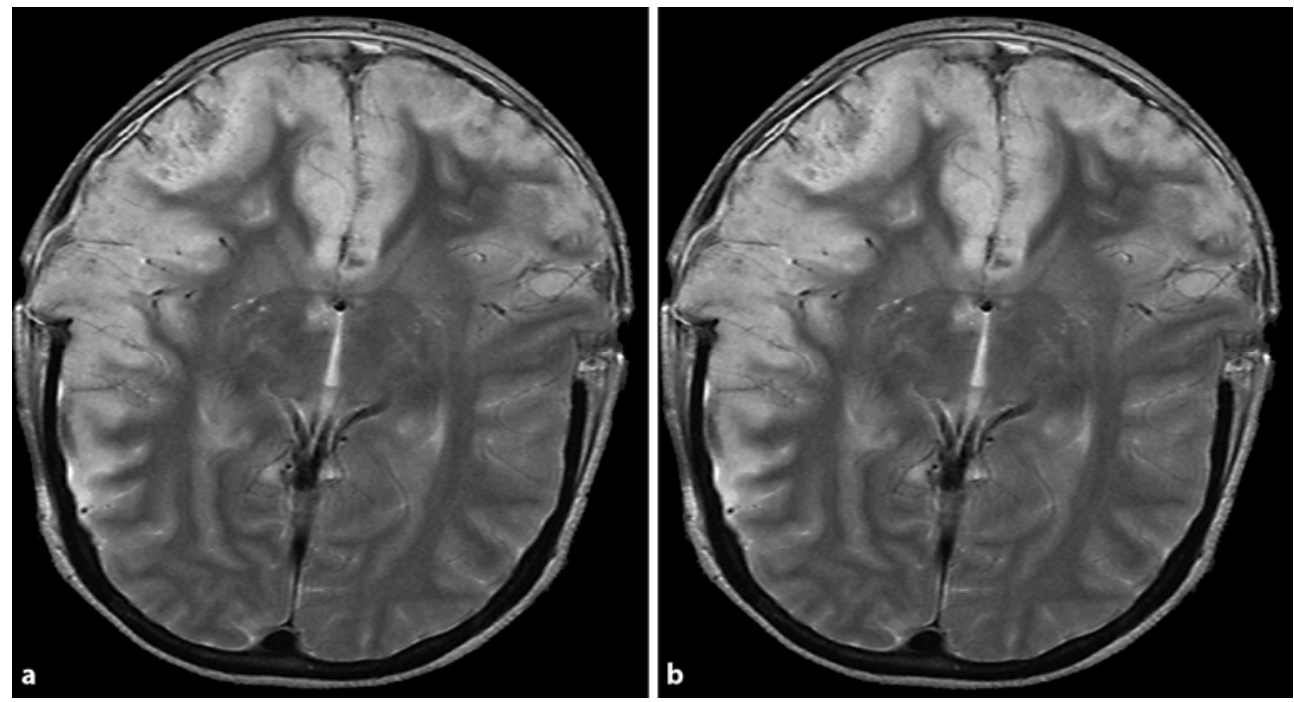

Fig. 3. T2 MRI after bilateral decompressive craniectomy demonstrating cortical bilateral hyperintensity shown as anoxic lesions.

\section{References}

1 Hanel RA, Prevedello DM, Correa A, Antoniuk A, Araujo JC: Cerebrospinal fluid fistula as the presenting manifestation of pituitary adenoma: case report with a 4-year follow-up. Arq Neuropsiquiatr 2001;59:263-265.

-2 Smidt MH, van der Vliet A, Wesseling P, de Vries J, Twickler TB, Vos PE: Pituitary apoplexy after mild head injury misinterpreted as bacterial meningitis. Eur J Neuol 2007;14:e7-e8.

-3 Eljamel MS, Foy PM: Non-traumatic CSF fistulae: clinical history and management. Br J Neurosurg 1991;5:275-279.

4 Onoda N, Kamezu Y, Takagi S, Shinohara Y, Osamura RY: An autopsy case of pituitary adenoma (prolactinoma) with rapid fatal clinical course due to streptococcal meningitis. Acta Pathol Jpn 1992;42:832836.

-5 Ohtakara K, Matsubara T, Kojima T, Taki W, Waga S: Cerebrospinal fluid rhinorrhea associated with untreated prolactinoma - case report. Neurol Med Chir (Tokyo) 2000;40:413-418.

6 Lindstrom DR, Toohill RJ, Loehrl TA, Smith TL: Management of cerebrospinal fluid rhinorrhea: the Medical College of Wiscontin experience. Laryngoscope 2004;114:969-974.

7 Nutkiewicz A, DeFeo DR, Kohut RI, Fierstein S: Cerebrospinal fluid rhinorrhea as a presentation of pituitary adenoma. Neurosurgery 1980;6:195-197.

8 Telera S, Conte A, Cristalli G, Occhipinti E, Pompili A: Spontaneous cerebrospinal fluid rhinorrhea as the presenting symptom of sellar pathologies: three demonstrative cases. Neurosurg Rev 2007;30:78-82.

-9 Laszewski MJ, Moore SA: Occult invasive pituitary adenoma predisposing to fatal bacterial meningitis. Clin Neuropathol 1990;9:101-105.

10 Hanel RA, Koerbel A, Monte Serrat Prevedello D, Moro MS, Araujo JC: Primary pituitary abscess: case report. Arq Neuropsiquiatr 2002;60:861-865.

11 Utsuki S, Oka H, Tanaka S, Iwamoto K, Hasegawa H, Hirose R, Fujii K: Prolactinoma with a high adrenocorticotropic hormone level caused by meningitis - case report. Neurol Med Chir (Tokyo) 2004;44,8689.

12 Honegger J, Psaras T, Petrick M, Reincke M: Meningitis as a presentation of macroprolactinoma. Exp Clin Endocrinol Diabetes 2009;117:361-364.

13 Jeon BC, Park YS, Oh HS, Kim YS, Chun BK: Pituitary apoplexy complicated by chemical meningitis and cerebral infarction. J Korean Med Sci 2007;22:1085-1089.

-14 Lindvall P, Ahlm C, Ericsson M, Gothefors L, Naredi S, Koskinen LO: Reducing intracranial pressure may increase survival among patients with bacterial meningitis. Clin Infect Dis 2004;38:384-390. 
15 Baussart B, Cheisson G, Compain M, Leblanc PE, Tadie M, Benhamou D, Duranteau J: Multimodal cerebral monitoring and decompressive surgery for the treatment of severe bacterial meningitis with increased intracranial pressure. Acta Anaesthesiol Scand 2006;50:762-765.

-16 Taferner E, Pfausler B, Kofler A, Spiss H, Engelhart K, Kampfl A, Schmutzhard E: Craniectomy in severe, life-threatening encephalitis: a report on outcome and long-term prognosis of four cases. Intensive Care Med 2001;27:1426-1428.

17 Adamo MA, Deshaies EM: Emergency decompressive craniectomy for fulminating infectious encephalitis. J Neurosurg 2008;108:174-176. 